\title{
ORIGINAL ARTICLE Blood pressure-lowering effects of nifedipine/candesartan combinations in high-risk individuals: subgroup analysis of the DISTINCT randomised trial
}

\author{
G Mancia ${ }^{1}$, G Cha ${ }^{2}$, B Gil-Extremera ${ }^{3}$, P Harvey ${ }^{4}$, AJ Lewin ${ }^{5}$, G Villa ${ }^{6}$ and SE Kjeldsen ${ }^{7}$ for the DISTINCT Investigators
}

The DISTINCT study (reDefining Intervention with Studies Testing Innovative Nifedipine GITS-Candesartan Therapy) investigated the efficacy and safety of nifedipine GITS/candesartan cilexetil combinations vs respective monotherapies and placebo in patients with hypertension. This descriptive sub-analysis examined blood pressure (BP)-lowering effects in high-risk participants, including those with renal impairment (estimated glomerular filtration rate $<90 \mathrm{ml} \mathrm{min}^{-1}, n=422$ ), type 2 diabetes mellitus ( $n=202$ ), hypercholesterolaemia $(n=206)$ and cardiovascular $(C V)$ risk factors $(n=971)$, as well as the impact of gender, age and body mass index (BMI). Participants with grade I/II hypertension were randomised to treatment with nifedipine GITS (N) 20, 30, 60 mg and/or candesartan cilexetil (C) 4, 8, 16, 32 mg or placebo for 8 weeks. Mean systolic BP and diastolic BP reductions after treatment in high-risk participants were greater, overall, with N/C combinations vs respective monotherapies or placebo, with indicators of a dose-response effect. Highest rates of BP control (ESH/ESC 2013 guideline criteria) were also achieved with highest doses of N/C combinations in each high-risk subgroup. The benefits of combination therapy vs monotherapy were additionally observed in patient subgroups categorised by gender, age or BMI. All high-risk participants reported fewer vasodilatory adverse events in the pooled N/C combination therapy than the N monotherapy group. In conclusion, consistent with the DISTINCT main study outcomes, high-risk participants showed greater reductions in BP and higher control rates with N/C combinations compared with respective monotherapies and lesser vasodilatory side-effects compared with $\mathrm{N}$ monotherapy.

Journal of Human Hypertension (2017) 31, 178-188; doi:10.1038/jhh.2016.54; published online 11 August 2016

\section{INTRODUCTION}

Individuals with hypertension who have comorbidities such as diabetes mellitus, renal impairment or established cardiovascular (CV) disease are at increased risk of future events and mortality. ${ }^{1-4}$ Prompt initiation of treatment is recommended in individuals with grade 2 or 3 hypertension and any level of $\mathrm{CV}$ risk ${ }^{2,5}$ because a short time-to-effect has been demonstrated between increased blood pressure (BP) control and reduction in CV risk. ${ }^{6}$ To achieve an optimal time-to-effect, many guidelines recommend initial combination therapy using agents that have complementary mechanisms of action. 2,7

Angiotensin II is known to have a role in the progression of diabetic nephropathy. ${ }^{8}$ Recent guidelines recommended initiating therapy including a renin angiotensin system (RAS) blocker in patients with chronic kidney disease (CKD) owing to beneficial renal outcomes., ${ }^{2,7}$ Unlike $\beta$-blockers or diuretics, calcium channel blockers (CCB) are not associated with adverse effects on glucose and lipid metabolism ${ }^{7,9}$ and, thus, are not considered of concern in patients with diabetes or metabolic syndrome. Furthermore, the combination of a CCB with a RAS blocker has the potential for greater BP reductions compared with monotherapy, especially in high-risk patients in whom BP control is more difficult, ${ }^{2}$ can reduce peripheral oedema (vs CCB monotherapy $)^{10,11}$ and attenuate renal hyperfiltration. ${ }^{12}$
Although a number of angiotensin receptor blocker (ARB)-CCB fixed-dose combinations are available, none have previously contained the extended-release formulation of nifedipine GITS. The potential benefits of a nifedipine GITS-ARB combination in high-risk patients is, therefore, clinically interesting. DISTINCT (reDefining Intervention with Studies Testing Innovative Nifedipine GITS-Candesartan Therapy) was an 8-week, randomised, double-blind, placebo-controlled, parallel-group, multifactorial study that evaluated the efficacy and safety of dose combinations of nifedipine GITS and candesartan cilexetil, compared with respective monotherapies and placebo, in patients with grade 1 or 2 hypertension. ${ }^{11}$ In DISTINCT, the ARB-CCB combination was effective and well tolerated, with each component contributing independently to BP reductions; the combination also significantly reduced vasodilatory side-effects compared with nifedipine GITS monotherapy.

The current descriptive subgroup analyses of DISTINCT investigated the BP-lowering effects and tolerability of nifedipine GITS-candesartan cilexetil combinations in high-risk participants, including those with renal impairment, type 2 diabetes mellitus (T2DM), hypercholesterolaemia and an aggregate of CV risk factors (T2DM or body mass index $(\mathrm{BMI}) \geqslant 30 \mathrm{~kg} \mathrm{~m}^{-2}$ or low-density lipoprotein (LDL) cholesterol $\geqslant 130 \mathrm{mg} \mathrm{dl}^{-1}$ ), as well as assessing the effects of gender, age and BMI.

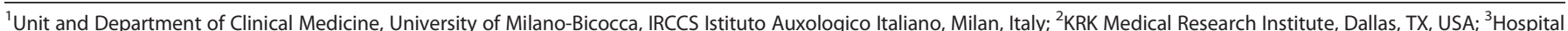

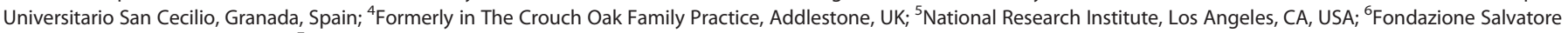

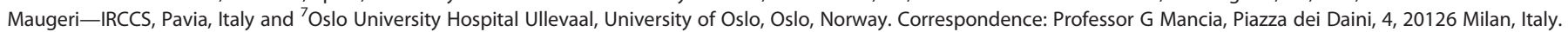
E-mail: giuseppe.mancia@unimib.it

Received 7 October 2015; revised 2 March 2016; accepted 14 March 2016; published online 11 August 2016 


\section{METHODS}

Study design

Details of the DISTINCT study design have been reported previously ${ }^{11}$ (clinicaltrials.gov identifier NCT01303783). In brief, DISTINCT was an 8-week, multi-national, multi-centre, randomised, double-blind, placebocontrolled, multifactorial study to determine the dose-response of 16 combinations of nifedipine GITS (N) $0,20,30$ or $60 \mathrm{mg}$ and/or candesartan cilexetil (C) $0,4,8,16$ or $32 \mathrm{mg}$ in participants with grade 1 and 2 hypertension. Following a 2-week ( \pm 3 days) screening/washout period and a 2-4 week, single-blind, placebo run-in, participants were randomised in equal ratios to one of the 16 treatment groups. For subjects randomised to the highest dose (N60C32), there was a forced dose titration period of one week, during which $\mathrm{N} 30 \mathrm{C} 16$ was administered. Subjects were instructed to take their medication with water at the same time in the morning $(8: 00 \pm 2 \mathrm{~h})$, except on the day of a visit.

The study was conducted in accordance with the Declaration of Helsinki and the International Conference on Harmonization guidelines on good clinical practice. The study protocol was reviewed and approved by each centre's independent ethics committee or institutional review board. All participants provided written informed consent prior to study entry. Standardsation across investigator sites was maintained by establishment of a detailed clinical protocol and through monitoring adherence to the protocol by COVANCE Inc. (Indianapolis, IN, USA).

\section{Population}

DISTINCT included men and women aged 18 years or older with grade 1 or 2 hypertension according to the World Health Organization/International Society of Hypertension 2003 guidelines. ${ }^{13}$ Patients were recruited from 131 study centres in 12 countries (Argentina, Belgium, Canada, Italy, Lithuania, Russia, South Africa, South Korea, Spain, Ukraine, UK and USA) between 28 April 2011 and 28 May 2012. ${ }^{11}$ BP was measured by a calibrated electronic device (Model HEM-705CP; Omron Healthcare, Inc., Bannockburn, IL, USA), with a cuff of appropriate size, supplied with instructions for use by Bayer HealthCare AG (Berlin, Germany). Patients were required to have a mean seated diastolic $B P(D B P) \geqslant 95 \mathrm{~mm} \mathrm{Hg}$ and $<110 \mathrm{~mm} \mathrm{Hg}$ at randomisation, and an absolute difference in mean seated DBP of $<10 \mathrm{~mm} \mathrm{Hg}$ between screening and randomisation, consistent with the guidelines current at the time of study planning and in agreement with other phase llb dose-finding studies of CCB/ARB fixeddose agents (for example, amlodipine/valsartan, amlodipine/olmesartan and amlodipine/telmisartan). ${ }^{13-16}$ Inclusion and exclusion criteria have been described previously. ${ }^{11}$

The current subgroup analysis focuses on BP lowering in participants in DISTINCT with renal impairment, T2DM, hypercholesterolaemia and CV risk factors, as well as patients categorised by gender, age and BMI. Renal impairment was defined by an estimated glomerular filtration rate (eGFR)
$<60 \mathrm{ml} \mathrm{min}^{-1}$ (that is, moderate/severe) and $<90 \mathrm{ml} \mathrm{min}^{-1}$ (that is, any grade of renal impairment) at baseline. ${ }^{17,18}$ Hypercholesterolaemia was defined as total cholesterol $>240 \mathrm{mg} \mathrm{dl}^{-1}$.,19 $\mathrm{CV}$ risk factors were defined as T2DM, BMI $\geqslant 30 \mathrm{~kg} \mathrm{~m}^{-2}$ (obesity), LDL cholesterol $\geqslant 130 \mathrm{mg} \mathrm{dl}^{-1}$ or any combination of these factors. ${ }^{20}$ The potential impacts of age and BMI were assessed by analysis of tertiles (age: $<55,55-64$ and $\geqslant 64$ years; BMI: $<25$, $25-29$ and $\geqslant 30 \mathrm{~kg} \mathrm{~m}^{-2}$ ). Analyses of specific high-risk groups (that is, renal impairment and T2DM) were prespecified in the study protocol; additional analyses were performed post hoc. ${ }^{11}$

\section{Assessments}

Visits during the double-blind treatment period were at 1, 2, 4, 6 and 8 weeks post-baseline. BP was measured between 08:00 and 09:00 h. BP measurements were performed in both arms at first visit and the arm with highest BP reading was used for all subsequent measurements. At each visit, patients were required to sit for at least $5 \mathrm{~min}$, after which three BP measurements were taken 2 min apart, always with the patient in the seated position. The arithmetic mean BP was considered to be the representative value of the visit.

The prespecified measurements of interest were: (1) Change from baseline in mean seated DBP and systolic BP (SBP) and (2) BP control rate after 8 weeks of treatment. BP control was defined as the proportion of patients achieving a BP of $<140 / 90 \mathrm{~mm} \mathrm{Hg}$, with the exception of participants with T2DM in any high-risk group, whose control rate was based on $<140 / 85 \mathrm{~mm} \mathrm{Hg}$ to reflect recommendations in the latest ESH/ ESC guidelines. ${ }^{2}$ Control rates are also presented based on $\mathrm{BP}<130$ $180 \mathrm{~mm} \mathrm{Hg}$ at 8 weeks in patients with renal impairment or T2DM, as recommended by ESH/ESC guidelines at the time of study. ${ }^{21}$

Prespecified analyses of participants with renal impairment in DISTINCT included a cutoff for eGFR of $<60 \mathrm{ml} \mathrm{min}^{-1}$ (representing moderate/severe renal impairment). Post hoc analyses in the current paper additionally include an eGFR cutoff of $<90 \mathrm{ml} \mathrm{min}^{-1}$ (that is, all grades of renal impairment) to provide increased numbers of patients for analysis and greater scope for generalisation.

Treatment-emergent adverse events (AE) and their relationship to treatment were recorded in all groups. The occurrence and severity of peripheral oedema were assessed at all scheduled visits. Incidences of headache were determined by participant self-reports.

\section{Statistical analyses}

Efficacy analyses in the DISTINCT main study included all randomised subjects who received at least one dose of study medication and had a baseline as well as at least one valid post-baseline BP measurement ('full analysis set'). The current efficacy analyses included all subjects in the full analysis set who had the identified risk factors at baseline. Patients in the full analysis set without these risk factors were also analysed for

Table 1. Baseline characteristics of high-risk and non-high-risk individuals (safety analysis set)

\begin{tabular}{|c|c|c|c|c|c|c|c|c|c|c|c|}
\hline Characteristic & \multicolumn{2}{|c|}{$\begin{array}{c}\text { Renal impairment of any } \\
\text { grade (baseline } \\
\text { eGFR }<90 \mathrm{ml} \mathrm{min}^{-1} \text { ) }\end{array}$} & \multicolumn{2}{|c|}{$T 2 D M$} & \multicolumn{3}{|c|}{$\begin{array}{l}\text { Hypercholesterolaemia (total } \\
\text { cholesterol }>240 \mathrm{mg} \mathrm{dll}^{-1} \text { ) }\end{array}$} & \multicolumn{4}{|c|}{$\begin{array}{c}C V \text { risk factor(s) (T2DM or } B M I \geqslant 30 \mathrm{~kg} \mathrm{~m}^{-2} \text { or } \\
\left.L D L \geqslant 130 \mathrm{mg} \mathrm{dl}^{-1}\right)\end{array}$} \\
\hline $\begin{array}{l}\text { Age, years, mean } \\
\text { Male, } n(\%)\end{array}$ & $\begin{array}{c}61.6 \\
232(54.5 \%)\end{array}$ & $\begin{array}{c}50.6 \\
567(59.4 \%)\end{array}$ & $\begin{array}{c}56.8 \\
116(56.6 \%)\end{array}$ & $\begin{array}{c}53.5 \\
683(58.1 \%)\end{array}$ & $\begin{array}{c}55.2 \\
110(52.4 \%)\end{array}$ & $\begin{array}{c}54.0 \\
245(54.0 \%)\end{array}$ & $\begin{array}{c}53.7 \\
442(61.8 \%)\end{array}$ & $\begin{array}{c}53.7 \\
547(55.5 \%)\end{array}$ & $\begin{array}{c}53.7 \\
534(55.7 \%)\end{array}$ & $\begin{array}{c}53.4 \\
390(57.4 \%)\end{array}$ & $\begin{array}{c}54.8 \\
\text { b) } 252(63.8 \%)\end{array}$ \\
\hline $\begin{array}{l}\text { BMI, } \mathrm{kg} \mathrm{m}^{-2} \text {, mean } \\
\text { Obesity } \\
\left(\mathrm{BMI} \geqslant 30 \mathrm{~kg} \mathrm{~m}^{-2}\right), \\
n(\%)\end{array}$ & $109(25.6 \%)$ & $\begin{array}{ll}32.6 \\
619(64.8 \%)\end{array}$ & $129(62.9 \%)$ & $\begin{array}{l}30.8 \\
599(50.9 \%)\end{array}$ & $\begin{array}{c}30.4 \\
97(46.2 \%)\end{array}$ & $\begin{array}{c}31.2 \\
242(53.3 \%)\end{array}$ & $\begin{array}{c}31.1 \\
389(54.4 \%)\end{array}$ & $\begin{array}{c}32.9 \\
728(73.8 \%)\end{array}$ & $\begin{array}{c}32.8 \\
700(73.1 \%)\end{array}$ & $\begin{array}{l}32.2 \\
437(64.4 \%)\end{array}$ & $393(99.5 \%)$ \\
\hline
\end{tabular}




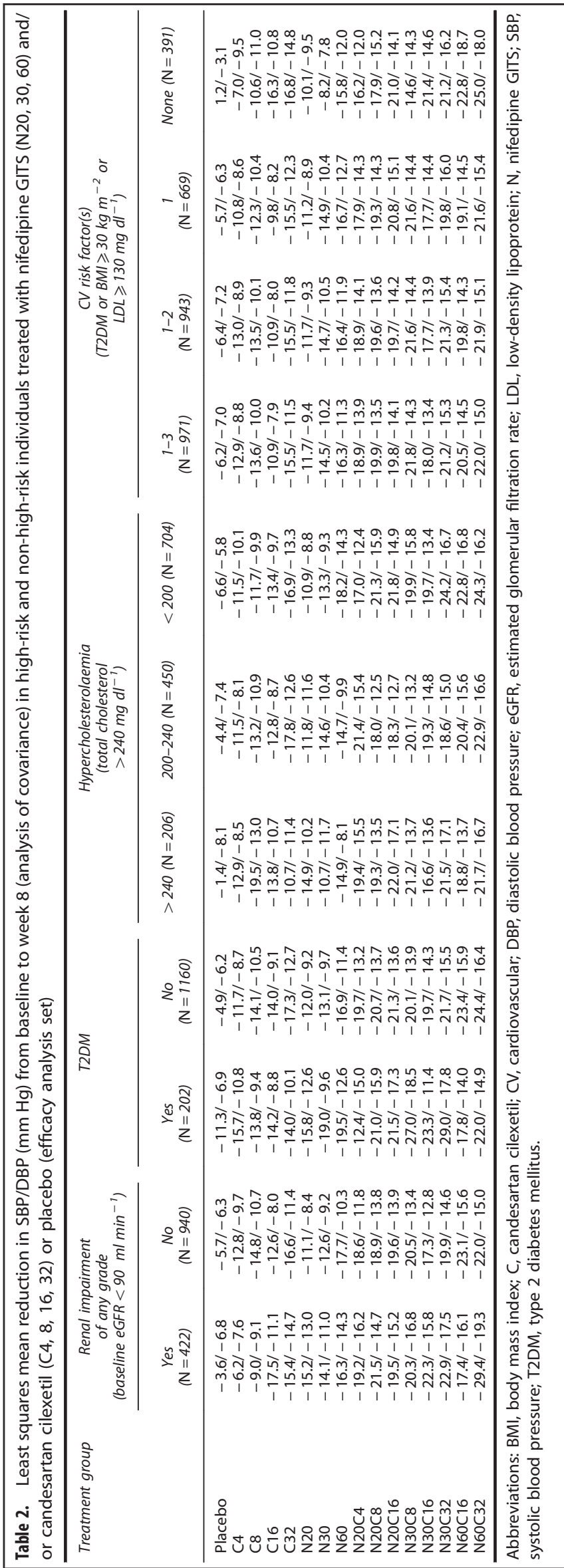

comparative purposes. Descriptive analyses were performed for the change from baseline in mean SBP and DBP and for control rates utilising the criteria described above. DBP and SBP changes from baseline are presented as least squares means, calculated using analysis of covariance, with treatment, (pooled) centres, BP and age at baseline as covariates. Missing values are imputed by the last observation carried forward approach.

Safety analyses include all randomised subjects who took at least one dose of study drug. Participants with treatment-emergent AEs are analysed according to pooled treatment groups: nifedipine GITS-candesartan cilexetil combination, nifedipine GITS or candesartan cilexetil monotherapy, or placebo, as in the main DISTINCT study. ${ }^{11}$

Analyses were performed using SAS software 9.2 (SAS Institute Inc., Cary, NC, USA).

\section{RESULTS}

Demographics

A total of 2817 patients were screened and 1381 (49.0\%) were randomised to treatment in the main DISTINCT study (Supplementary Materials Supplementary Figure 1). ${ }^{11}$ Of these patients, $30.8 \%(n=426)$ had renal impairment of any grade $\left(\mathrm{eGFR}<90 \mathrm{ml} \mathrm{min}^{-1}\right)$, including $3.6 \% \quad(n=50)$ with moderate/severe renal impairment (eGFR $<60 \mathrm{ml} \mathrm{min}^{-1}$ ); $14.8 \%$ $(n=205)$ had T2DM; $15.2 \%(n=210)$ had hypercholesterolaemia and $71.4 \%(n=986)$ had CV risk factors. Baseline characteristics of patients with renal impairment, T2DM, hypercholesterolaemia and CV risk factors are provided in Table 1. Approximately one-half of high-risk participants were male, with an age range of 53.7-61.6 years and approximately one-half in each group were obese. The high-risk populations were generally well matched in baseline characteristics with the main DISTINCT study population ${ }^{11}$ and with patient subgroups without the high-risk conditions, although the subgroup with renal impairment was older (mean 62 vs 51 years), had lower BMI ( 27 vs $33 \mathrm{~kg} \mathrm{~m}^{-2}$ ) and included a larger proportion of Asian and fewer Black participants than the subgroup without renal impairment (Table 1).

\section{Efficacy}

The efficacy analysis set in the main DISTINCT study included 1362 individuals. ${ }^{11}$ Of this population, the high-risk participants included 422 with renal impairment of any grade $\left(\right.$ eGFR $\left.<90 \mathrm{ml} \mathrm{min}^{-1}\right)$, including 50 with moderate/severe renal impairment $\left(e G F R<60 \mathrm{ml} \mathrm{min}^{-1}\right.$ ), 202 with T2DM, 206 with hypercholesterolaemia and 971 with CV risk factors. These subgroups were investigated for efficacy in the current analyses. Additional subgroup analyses according to gender (male, $n=788$ ), and tertiles of age ( $<55$ years, $n=701 ; 55-64, n=463 ; \geqslant 65$, $n=198)$ and BMl ( $<25 \mathrm{~kg} \mathrm{~m}^{-2}, n=172 ; 25-29, n=467 ; \geqslant 30$, $n=719)$ are also included in the Supplementary Materials.

$B P$ changes. As reported for the main DISTINCT study population, ${ }^{11}$ mean changes in SBP/DBP in high-risk participants were overall greater with combination therapy than respective monotherapies or placebo, with indicators of a dose-response effect (Table 2). In general, consistent trends were observed between high-risk participants and respective non-high-risk groups in terms of greater BP reduction in combination therapy compared with the respective monotherapies or placebo (Table 2).

Pooled treatment analyses demonstrated that early SBP/DBP reductions (that is, within the first 2 weeks of treatment) were superior for combination therapy vs each monotherapy in all high-risk groups, including those with renal impairment of any grade (Figure 1a), T2DM (Figure 1b), hypercholesterolaemia (Figure 1c) and any CV risk factors (Figure 1d). These group differences were sustained for the study duration. 
a
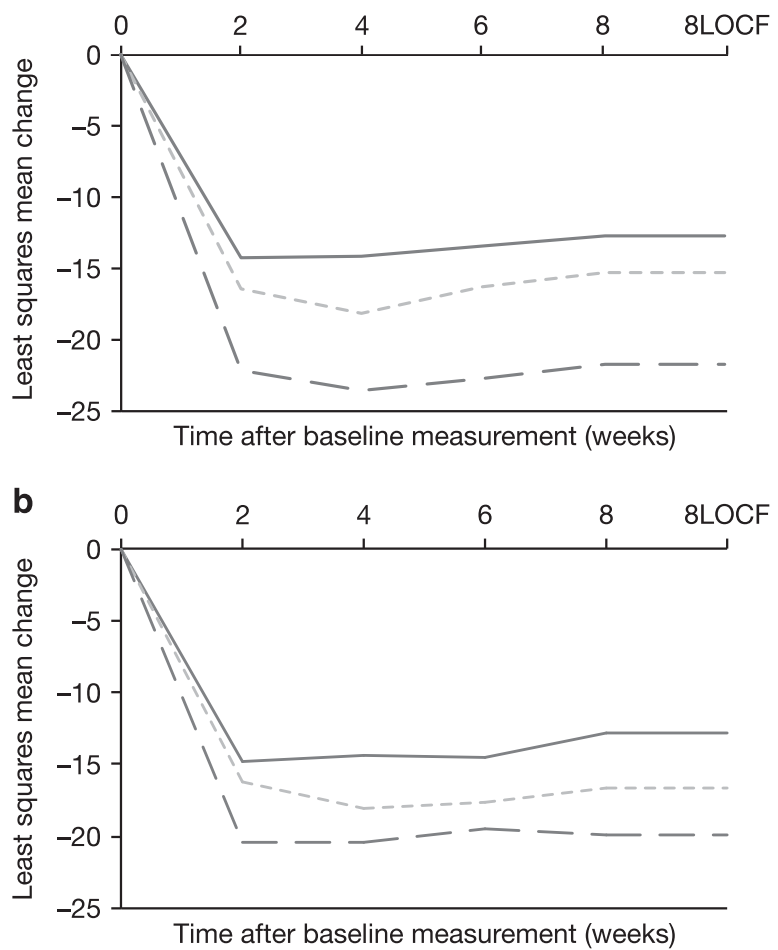

Time after baseline measurement (weeks)
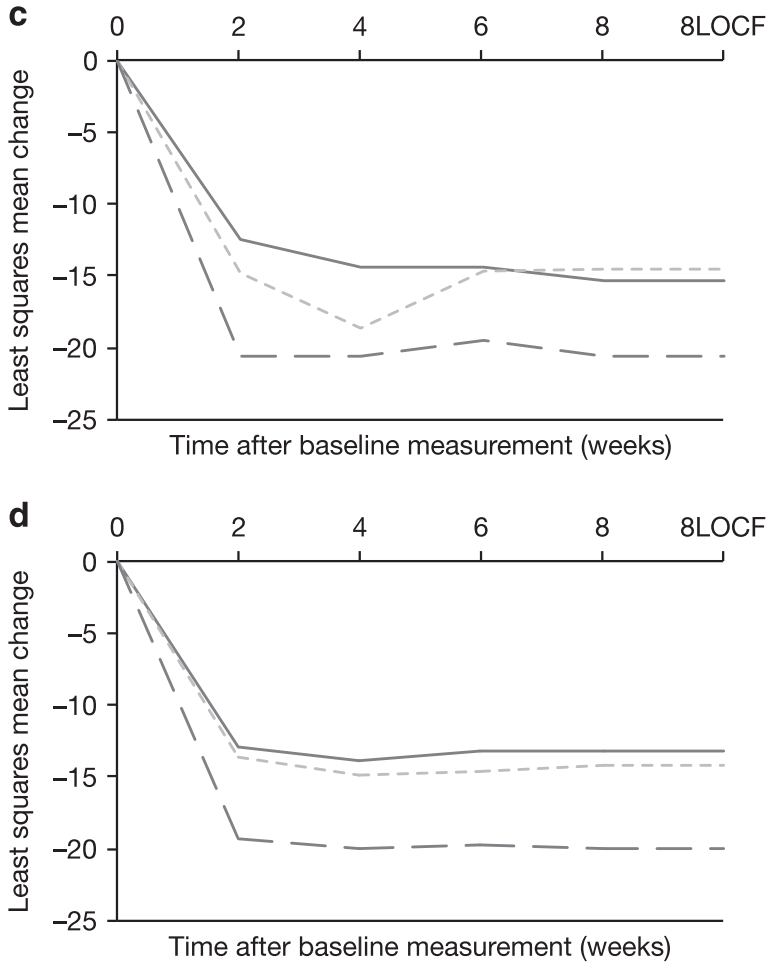

Diastolic BP, mmHg

$\begin{array}{llllll}0 & 2 & 4 & 6 & 8 & \text { 8LOCF }\end{array}$

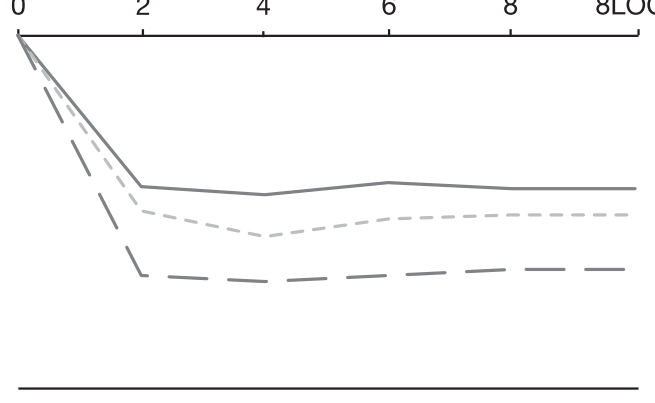

Time after baseline measurement (weeks)
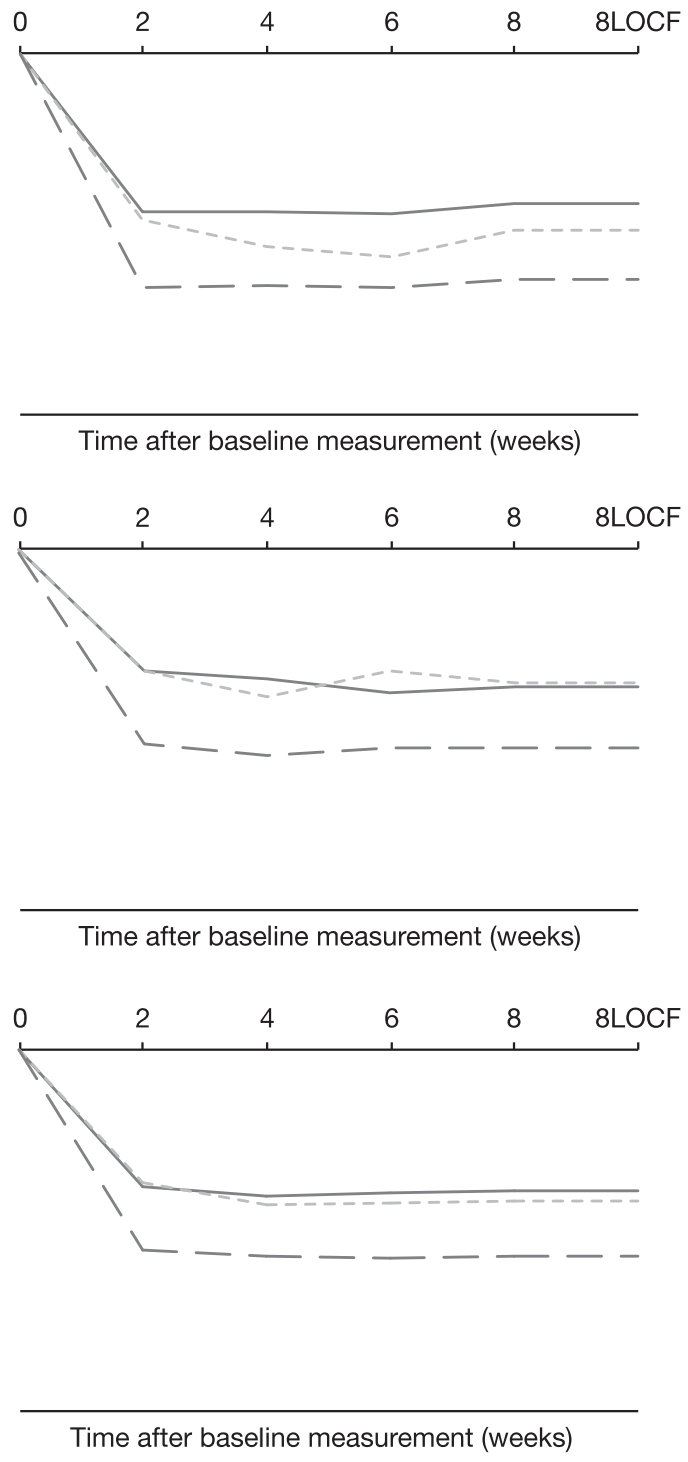

C mono - - N N mono - - N/C comb

Figure 1. Least squares mean change in SBP/DBP $(\mathrm{mm} \mathrm{Hg})$ during 8 weeks of treatment with nifedipine GITS (N20, 30, 60) and/or candesartan cilexetil $(C 4,8,16,32)$ in individuals with (a) renal impairment (baseline eGFR $<90 \mathrm{ml} \mathrm{min}{ }^{-1}$ ), (b) T2DM, (c) hypercholesterolaemia (total cholesterol $>240 \mathrm{mg} \mathrm{dl}^{-1}$ ) or (d) any CV risk factors (T2DM or BMI $\geqslant 30 \mathrm{~kg} \mathrm{~m}^{-2}$ or LDL $\geqslant 130 \mathrm{mg} \mathrm{dl}^{-1}$ ). Abbreviations: BMl, body mass index; $\mathrm{BP}$, blood pressure; C, candesartan cilexetil; CV, cardiovascular; DBP, diastolic blood pressure; eGFR, estimated glomerular filtration rate; LDL, low-density lipoprotein; N, nifedipine GITS; SBP, systolic blood pressure; T2DM, type 2 diabetes mellitus. 
BP control rates. In all high-risk participants, 8-week BP control rates (using ESH/ESC 2013 guidelines) were generally higher with combination therapy than monotherapies or placebo, with indicators of a dose-response effect (Table 3, Figure 2). Findings were comparable using the stricter, prespecified definition for BP control of $<130 / 80 \mathrm{~mm} \mathrm{Hg}$.

In pooled treatment analyses, combination therapy was associated with earlier BP control compared with monotherapies in participants with renal impairment of any grade, T2DM, hypercholesterolaemia and CV risk factors (Figure 3a-d). These improvements were maintained throughout the study, consistent with the main outcomes.

Descriptive subgroup analyses based on gender and tertiles of both age and BMI demonstrated a similar greater treatment effect for combination therapy vs placebo and respective monotherapies for BP changes and BP control, as above, across patient groups (Supplementary Materials Supplementary Tables 1 and 2).

Safety

The safety analysis set in the main DISTINCT study included 1381 individuals. ${ }^{11}$ Of this population, 426 had renal impairment of any grade (eGFR $<90 \mathrm{ml} \mathrm{min}^{-1}$ ), including 50 with moderate/severe renal impairment (eGFR $<60 \mathrm{ml} \mathrm{min}^{-1}$ ), 205 had T2DM, 210 had hypercholesterolaemia and 986 had CV risk factors. These subgroups were investigated for safety in the current analyses.

At least one treatment-emergent AE was reported in 141/426 participants (33.1\%) with renal impairment of any grade, 61/205 (29.8\%) with T2DM, 64/210 (30.5\%) with hypercholesterolaemia and 382/986 (38.7\%) with CV risk factors (Table 4). The treatmentemergent AEs led to discontinuation of study drug in $12(2.8 \%)$ participants with renal impairment of any grade, 4 (2.0\%) with T2DM, 5 (2.4\%) with hypercholesterolaemia and 18 (1.8\%) with CV risk factors. In pooled treatment analyses, the highest rate of treatment-emergent AEs was consistently in high-risk patients taking nifedipine GITS monotherapy compared with combination therapy $(40.2 \%$ vs $36.2 \%$ of those with renal impairment of any grade, $34.9 \%$ vs $34.0 \%$ with $\mathrm{T} 2 \mathrm{DM}, 34.9 \%$ vs $29.7 \%$ with hypercholesterolaemia and $43.7 \%$ vs $41.9 \%$ with CV risk factors). It is notable that treatment-emergent AEs in these subgroups appeared to occur at generally similar or lower rates than in participants without the high-risk conditions (Table 4).

Vasodilatory treatment-emergent AEs occurred at a lower rate with combination therapy vs nifedipine GITS monotherapy in all high-risk participants (renal impairment of any grade: $12.2 \%$ vs 23.0\%; T2DM: $14.4 \%$ vs $18.6 \%$; hypercholesterolaemia: $13.9 \%$ vs $18.6 \%$; any CV risk factors: $20.3 \%$ vs $25.1 \%$ ) (Table 4$)$. These rates were also, overall, lower among the high-risk participants compared with the non-high-risk participants. Incidences of oedema during 8-week treatment were consistently lower with combination therapy than nifedipine GITS monotherapy at all times for each high-risk subgroup (Figure $4 a-d$ ).

Safety analyses based on gender, age and BMI demonstrated similar rates of total treatment-emergent $A E s$ and vasodilatory treatment-emergent $\mathrm{AEs}$ in combination therapy, respective monotherapies and placebo groups, when compared with the main study population, without evident differences between males or females, tertiles of age or BMI (Supplementary Materials Supplementary Table 3).

\section{DISCUSSION}

These subgroup analyses of DISTINCT show that nifedipine GITScandesartan cilexetil combinations are more effective than respective monotherapies or placebo for BP lowering in highrisk populations, including those with renal impairment, diabetes, hypercholesterolaemia or CV risk factors. Combination therapy 
a

Renal impairment (baseline eGFR $<90 \mathrm{~mL} / \mathrm{min}$ )

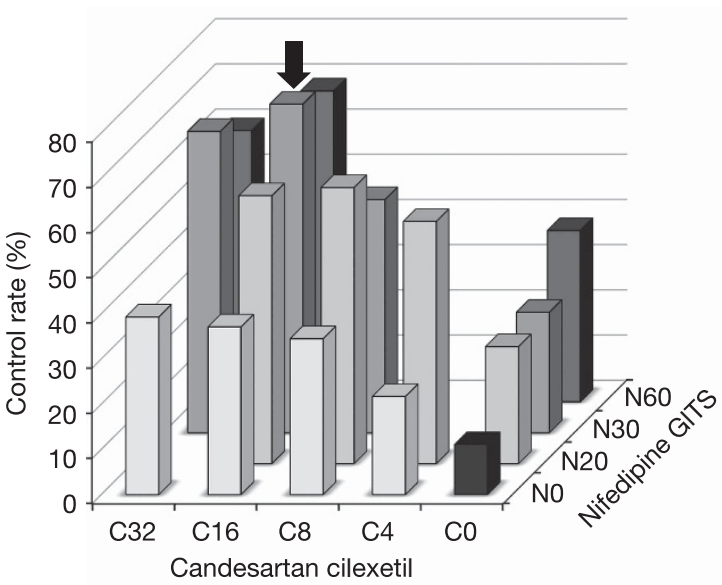

Hypercholesterolaemia (total cholesterol > $240 \mathrm{mg} / \mathrm{dL}$ )

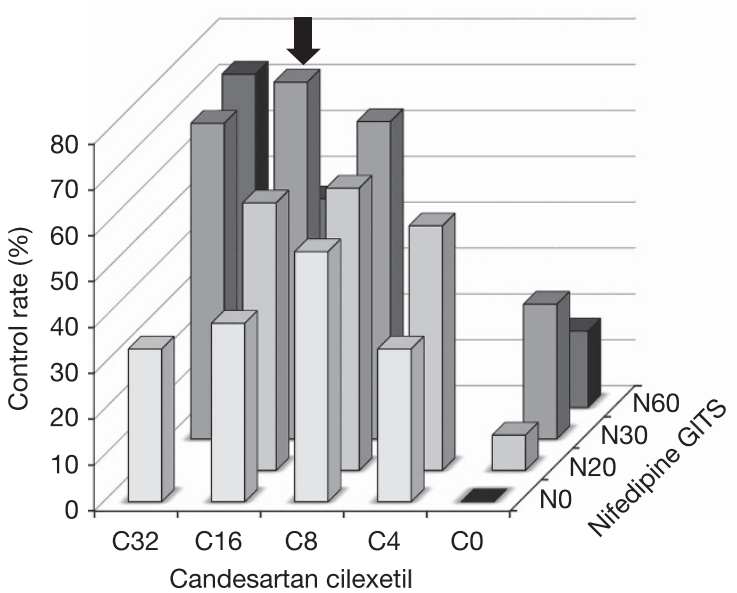

b

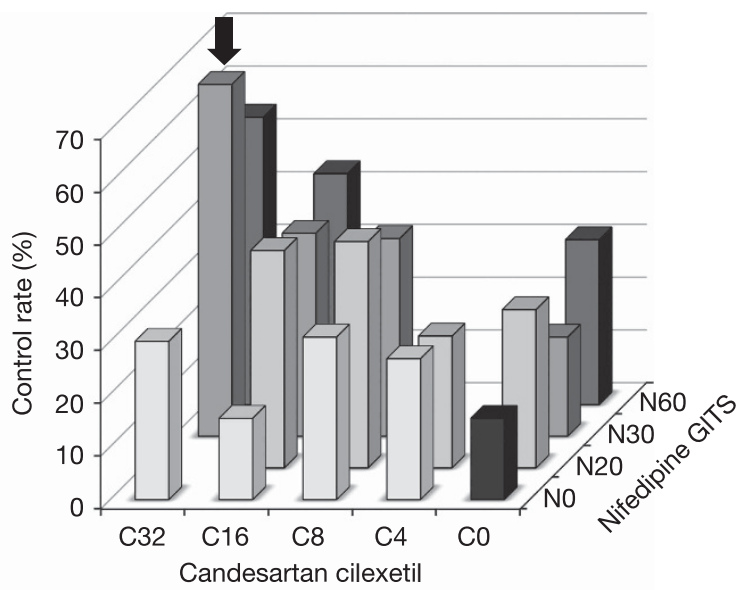

d
Any CV risk factors (T2DM or BMI $\geq 30 \mathrm{~kg} / \mathrm{m}^{2}$

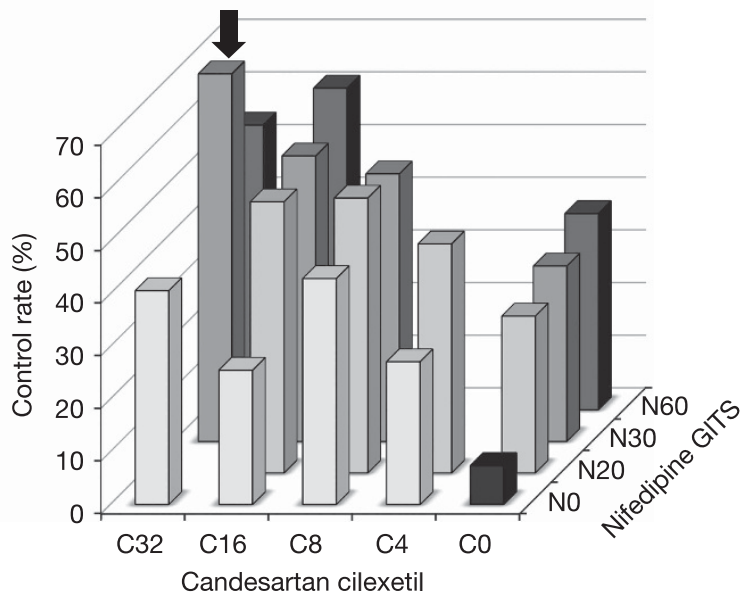

Figure 2. Stratified BP control rates (ESH/ESC 2013: $<140 / 85 \mathrm{~mm} \mathrm{Hg}$ for diabetes patients in each treatment group and $<140 / 90 \mathrm{~mm}$ Hg for all other patients, (\%) achieved at week 8 in high-risk individuals treated with nifedipine GITS (N20, 30,60) and/or candesartan cilexetil (C4, 8 , 16,32 ) or placebo. (a) Renal impairment (baseline eGFR $<90 \mathrm{ml} \mathrm{min}^{-1}$ ), (b) T2DM, (c) hypercholesterolaemia (total cholesterol $>240 \mathrm{mg} \mathrm{dl}^{-1}$ ) or (d) any CV risk factors (T2DM or BMI $\geqslant 30 \mathrm{~kg} \mathrm{~m}^{-2}$ or $\mathrm{LDL} \geqslant 130 \mathrm{mg} \mathrm{dl}^{-1}$ ). Arrow indicates dose group with highest BP control. Abbreviations: BMI, body mass index; BP, blood pressure; C, candesartan cilexetil; CV, cardiovascular; eGFR, estimated glomerular filtration rate; LDL, lowdensity lipoprotein; N, nifedipine GITS; T2DM, type 2 diabetes mellitus.

was associated with greater and earlier SBP/DBP reductions and increased BP control (regardless of the cutoff used) compared with respective monotherapies and these effects were sustained throughout the 8-week study. The magnitude of SBP/DBP lowering in these high-risk subgroups was broadly similar to the reductions observed in the main DISTINCT study and in individuals without these risk factors. ${ }^{11}$ These findings also applied to subgroup analyses based on gender, age and BMI.

The presence of renal impairment, T2DM, hypercholesterolaemia and obesity elevates the risk for CV events and for further decline of renal function in hypertensive patients, especially among older patients. ${ }^{2}$ Angiotensin-converting enzyme (ACE) inhibitors and ARBs are the preferred drug classes for antihypertensive therapy in patients with diabetes and renal impairment, given their superior renoprotective effects compared to other antihypertensive classes. ${ }^{22}$ Several randomised controlled trials have indicated more effective reductions in microalbuminuria or proteinuria using RAS inhibitors compared with other antihypertensive agents or placebo. ${ }^{12}$ Various studies across different patient subgroups, including those with T2DM,
CKD and diabetic nephropathy, have found a consistent reduction in urinary protein excretion endpoints associated with ARB use. ${ }^{23-25}$ Recent guidelines recommend combination therapy for high-risk patients to achieve target BP. ${ }^{2}$ Randomised, double-blind trials have demonstrated the antihypertensive efficacy of candesartan cilexeti $^{26}$ and CCB-ARB combination ${ }^{27}$ in diabetic populations. However, few randomised studies have investigated the effects of nifedipine GITS in high-risk populations with renal impairment or diabetes. ${ }^{28,29}$ The positive findings in this study of greater and earlier BP reductions in both high-risk groups supports the literature on the additive effects of combination therapy for hypertension.

A number of studies have also highlighted the CV benefits of CCB and RAS inhibitor therapy in high-risk patients. The INSIGHT study of 1302 individuals with hypertension and diabetes found similar incidence rates of primary CV outcomes (CV death, myocardial infarction, heart failure, stroke) and mean BP reductions for CCB (nifedipine GITS) and thiazide (co-amilozide) treatment. ${ }^{29}$ However, composite secondary outcomes (all-cause death, vascular-related death and non-vascular-related death) 

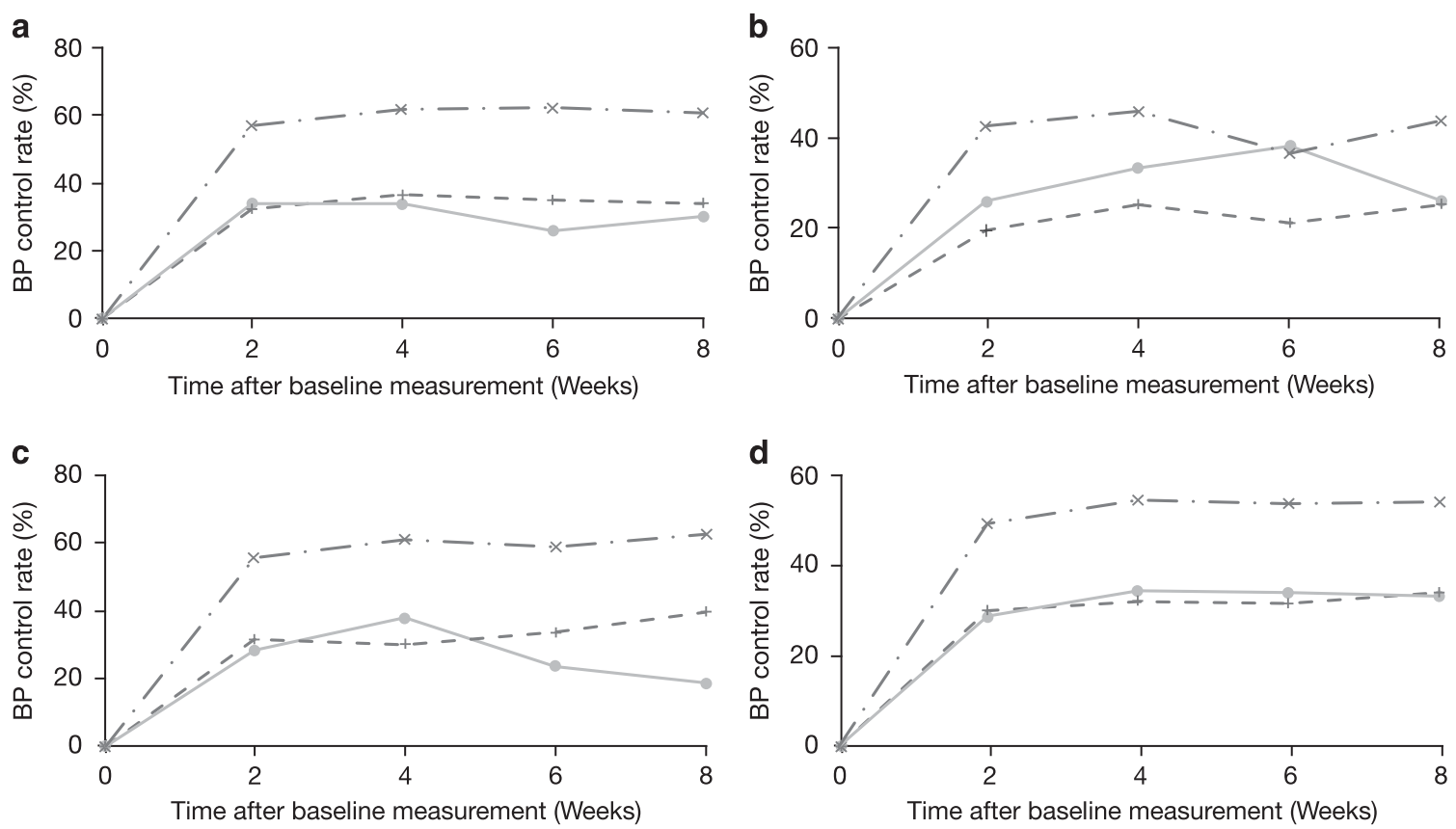

$$
-+ \text { C mono } \rightarrow-\mathrm{N} \text { mono } \rightarrow \text { * N/C comb }
$$

Figure 3. Stratified BP control rate (ESH/ESC 2013 guidelines: $<140 / 85 \mathrm{~mm} \mathrm{Hg}$ for patients with diabetes in each treatment group, $<140 / 90 \mathrm{~mm} \mathrm{Hg}$ for all other patients) during 8 weeks of treatment with nifedipine GITS (N20, 30, 60) and/or candesartan cilexetil (C4, 8,16 , 32) in individuals with (a) renal impairment of any grade (baseline eGFR $<90 \mathrm{ml} \mathrm{min}{ }^{-1}$ ), (b) T2DM, (c) hypercholesterolaemia (total cholesterol $>240 \mathrm{mg} \mathrm{dl}^{-1}$ ) or (d) any CV risk factors (T2DM or BMI $\geqslant 30 \mathrm{~kg} \mathrm{~m}^{-2}$ or LDL $\geqslant 130 \mathrm{mg} \mathrm{dl}^{-1}$. Abbreviations: BMI, body mass index; BP, blood pressure; C, candesartan cilexetil; CV, cardiovascular; eGFR, estimated glomerular filtration rate; LDL, low-density lipoprotein; $\mathrm{N}$, nifedipine GITS; T2DM, type 2 diabetes mellitus.

were significantly lower with nifedipine GITS than co-amilozide (14.2\% vs $18.7 \% ; P=0.03$ ). A post hoc analysis of the ACTION trial showed that adding nifedipine GITS to an existing antihypertensive regimen reduced $\mathrm{BP}$ by an average of $-6 /-3 \mathrm{~mm} \mathrm{Hg}$ in patients with diabetes and hypertension with controlled BP (mean $=140.7 / 79.8 \mathrm{~mm} \mathrm{Hg}$ ) at baseline. ${ }^{30}$ The ACCOMPLISH trial compared the combination of an ACE inhibitor (benazepril) with either a CCB (amlodipine) or thiazide diuretic (hydrochlorothiazide) and found superior outcomes with the CCB-ACE inhibitor combination in terms of reduced CV deaths, nonfatal myocardial infarction and nonfatal stroke ${ }^{31}$ and a significant reduction in CKD progression. $^{32}$ A subgroup analysis also found a significant reduction in the risk of a composite of CV outcomes among patients with diabetes receiving CCB-ACE inhibitor treatment (compared with diuretic-ACE inhibitor). ${ }^{33}$

Hypertension, glucose intolerance, central obesity and hypercholesterolaemia are components of a risk factor cluster (termed 'metabolic syndrome') for CV disease and T2DM. ${ }^{21}$ However, some of these risk factors have been found to impact differently according to gender, for example, greater CV heart disease mortality in women with diabetes compared to men. ${ }^{34}$ Given that more than a third of the DISTINCT study sample presented with at least one CV risk factor, this supports the literature that most of the hypertensive population rarely presents with elevated BP in isolation. $^{2}$ Recent ESC/EAS guidelines recommend LDL cholesterol-targeted interventions in hypertensive patients with CV risks, that is, those with metabolic syndrome, as these populations present a higher risk of CV diseases than the general population. ${ }^{35}$ The ASCOT-LLA trial demonstrated improved outcomes with the addition of a statin to the treatment regime for an average of 3 years, including reductions in major CV events and a lowering of total serum cholesterol. ${ }^{36}$
Nifedipine GITS-candesartan cilexetil combination therapy was associated in the current analyses with a lower incidence of vasodilatory treatment-emergent AEs compared with nifedipine GITS monotherapy, with an approximate halving of these side-effects for participants with renal impairment and a reduction of approximately one quarter for the diabetes, hypercholesterolaemia and CV risk factor subgroups. These improvements were largely due to reductions in the incidence of headache in high-risk subgroups, except for patients with hypercholesterolaemia. The incidence of oedema was also lower with combination therapy vs nifedipine GITS monotherapy in participants with renal impairment and hypercholesterolaemia, although not in those with diabetes or CV risk factors. CCB-associated oedema is a known side-effect of vasodilation, caused by increased intracapillary pressure which results in leakage of fluid into dependent soft tissue. This can be alleviated by concomitant use of a RAS blocker, which induces post-capillary venular relaxation therefore reducing CCV-related intracapillary pressure and capillary leakage. ${ }^{37}$ However, given the relatively common occurrence of a persistent dry cough with ACE inhibitors, ARBs may present a better tolerability profile with similar antihypertensive effectiveness. ${ }^{38}$

These analyses have some limitations. First, DISTINCT was not powered to enable subgroup comparisons, precluding meaningful statistical analyses. Second, the definition of BP control in the main DISTINCT study used a target of $<140 / 90 \mathrm{~mm} \mathrm{Hg}$ for the overall population and $<130 / 80 \mathrm{~mm} \mathrm{Hg}$ for those with renal impairment and/or diabetes. ${ }^{11}$ These definitions were included in the study protocol ahead of updates in the ESH/ESC (2013) guidelines, which now recommend a target of $<140 / 90 \mathrm{~mm} \mathrm{Hg}$ in patients with renal dysfunction and $<140 / 85 \mathrm{~mm} \mathrm{Hg}$ in those with diabetes. (Notably, there remains a lack of agreement on adopting less-aggressive BP targets, given the evidence from 
Table 4. Treatment-emergent AEs, $n / \mathrm{N}(\%)$ by pooled treatment with nifedipine GITS (N20, 30, $60 \mathrm{mg})$ and/or candesartan cilexetil (C4, 8, 16, $32 \mathrm{mg})$ or placebo in high-risk and non-high-risk individuals treated for 8 weeks (safety analysis set)

\begin{tabular}{|c|c|c|c|c|c|c|c|c|c|c|c|}
\hline \multirow[t]{2}{*}{$\begin{array}{l}\text { Pooled } \\
\text { treatment group }\end{array}$} & \multicolumn{2}{|c|}{$\begin{array}{l}\text { Renal impairment (baseline } \\
\quad \text { eGFR }<90 \mathrm{ml} \mathrm{min}{ }^{-1} \text { ) }\end{array}$} & \multicolumn{2}{|c|}{$T 2 D M$} & \multicolumn{3}{|c|}{$\begin{array}{l}\text { Hypercholesterolaemia (total } \\
\text { cholesterol }>240 \mathrm{mg} \mathrm{dl}^{-1} \text { ) }\end{array}$} & \multicolumn{4}{|c|}{$\begin{array}{c}\text { CV risk factor(s) (T2DM or } B M I \geqslant 30 \mathrm{~kg} \mathrm{~m}^{-2} \text { or } \\
\left.L D L \geqslant 130 \mathrm{mg} \mathrm{dl}^{-1}\right)\end{array}$} \\
\hline & Yes $(\mathrm{N}=426)$ & No $(\mathrm{N}=955)$ & Yes $(\mathrm{N}=205)$ & $\begin{array}{c}\text { No } \\
(\mathrm{N}=1176)\end{array}$ & $\begin{array}{l}>240 \\
(\mathrm{~N}=210)\end{array}$ & $\begin{array}{l}200-240 \\
(\mathrm{~N}=454)\end{array}$ & $\begin{array}{c}<200 \\
(\mathrm{~N}=715)\end{array}$ & $1-3(\mathrm{~N}=986)$ & $1-2(\mathrm{~N}=958)$ & $1(\mathrm{~N}=679)$ & $\begin{array}{l}\text { None } \\
(\mathrm{N}=395)\end{array}$ \\
\hline \multicolumn{12}{|c|}{ Any treatment-emergent $A E$} \\
\hline Total & $141(33.1 \%)$ & 395 (41.4\%) & $61(29.8 \%)$ & $\begin{array}{c}475 \\
(40.4 \%)\end{array}$ & $64(30.5 \%)$ & $176(38.8 \%)$ & 296 (41.4\%) & $382(38.7 \%)$ & $375(39.1 \%)$ & $277(40.8 \%)$ & $154(39.0 \%)$ \\
\hline Placebo & $3 / 27(11.1 \%)$ & $22 / 61(36.1 \%)$ & $2 / 14(14.3 \%)$ & $\begin{array}{l}23 / 74 \\
(31.1 \%)\end{array}$ & $\begin{array}{c}3 / 14 \\
(21.4 \%)\end{array}$ & $5 / 28(17.9 \%)$ & $17 / 46(37.0 \%)$ & $19 / 70(27.1 \%)$ & 19/69 (27.5\%) & $13 / 47(27.7 \%)$ & $\begin{array}{c}6 / 18 \\
(33.3 \%)\end{array}$ \\
\hline C & $\begin{array}{l}32 / 116 \\
(27.6 \%)\end{array}$ & $\begin{array}{l}78 / 230 \\
(33.9 \%)\end{array}$ & $\begin{array}{c}11 / 51 \\
(21.6 \%)\end{array}$ & $\begin{array}{l}99 / 295 \\
(33.6 \%)\end{array}$ & $\begin{array}{c}16 / 52 \\
(30.8 \%)\end{array}$ & $\begin{array}{l}33 / 104 \\
(31.7 \%)\end{array}$ & $\begin{array}{l}61 / 188 \\
(32.4 \%)\end{array}$ & $\begin{array}{l}79 / 246 \\
(32.1 \%)\end{array}$ & $\begin{array}{l}77 / 239 \\
(32.2 \%)\end{array}$ & $\begin{array}{l}53 / 162 \\
(32.7 \%)\end{array}$ & $\begin{array}{l}31 / 100 \\
(31.0 \%)\end{array}$ \\
\hline $\mathrm{N}$ & $\begin{array}{l}35 / 87 \\
(40.2 \%)\end{array}$ & $\begin{array}{l}74 / 167 \\
(44.3 \%)\end{array}$ & $\begin{array}{l}15 / 43 \\
(34.9 \%)\end{array}$ & $\begin{array}{l}94 / 211 \\
(44.5 \%)\end{array}$ & $\begin{array}{c}15 / 43 \\
(34.9 \%)\end{array}$ & $\begin{array}{c}41 / 83 \\
(49.4 \%)\end{array}$ & $\begin{array}{l}53 / 128 \\
(41.4 \%)\end{array}$ & $\begin{array}{l}80 / 183 \\
(43.7 \%)\end{array}$ & $\begin{array}{l}77 / 174 \\
(44.3 \%)\end{array}$ & $\begin{array}{l}63 / 132 \\
(47.7 \%)\end{array}$ & $\begin{array}{c}29 / 71 \\
(40.8 \%)\end{array}$ \\
\hline NC & $\begin{array}{l}71 / 196 \\
(36.2 \%)\end{array}$ & $\begin{array}{l}221 / 497 \\
(44.5 \%)\end{array}$ & $\begin{array}{c}33 / 97 \\
(34.0 \%)\end{array}$ & $\begin{array}{c}259 / 596 \\
(43.5 \%)\end{array}$ & $\begin{array}{l}30 / 101 \\
(29.7 \%)\end{array}$ & $\begin{array}{l}97 / 239 \\
(40.6 \%)\end{array}$ & $\begin{array}{l}165 / 353 \\
(46.7 \%)\end{array}$ & $\begin{array}{c}204 / 487 \\
(41.9 \%)\end{array}$ & $\begin{array}{c}202 / 476 \\
(42.4 \%)\end{array}$ & $\begin{array}{l}148 / 338 \\
(43.8 \%)\end{array}$ & $\begin{array}{l}88 / 206 \\
(42.7 \%)\end{array}$ \\
\hline \multicolumn{12}{|c|}{ Any study drug-related treatment-emergent $A E$} \\
\hline Placebo & $\begin{array}{c}2 / 27 \\
(7.4 \%)\end{array}$ & $\begin{array}{c}7 / 61 \\
(11.5 \%)\end{array}$ & $\begin{array}{c}1 / 14 \\
(7.1 \%)\end{array}$ & $\begin{array}{c}8 / 74 \\
(10.8 \%)\end{array}$ & $\begin{array}{c}1 / 14 \\
(7.1 \%)\end{array}$ & $0 / 28$ & $\begin{array}{c}8 / 46 \\
(17.4 \%)\end{array}$ & $\begin{array}{l}5 / 70 \\
(7.1 \%)\end{array}$ & $\begin{array}{c}5 / 69 \\
(7.2 \%)\end{array}$ & $\begin{array}{l}3 / 47 \\
(6.4 \%)\end{array}$ & $\begin{array}{c}4 / 18 \\
(22.2 \%)\end{array}$ \\
\hline $\mathrm{C}$ & $\begin{array}{l}7 / 116 \\
(6.0 \%)\end{array}$ & $\begin{array}{l}29 / 230 \\
(12.6 \%)\end{array}$ & $\begin{array}{c}2 / 51 \\
(3.9 \%)\end{array}$ & $\begin{array}{l}34 / 295 \\
(11.5 \%)\end{array}$ & $\begin{array}{c}7 / 52 \\
(13.5 \%)\end{array}$ & $\begin{array}{l}13 / 104 \\
(12.5 \%)\end{array}$ & $\begin{array}{l}16 / 188 \\
(8.5 \%)\end{array}$ & $\begin{array}{c}24 / 246 \\
(9.8 \%)\end{array}$ & $\begin{array}{c}22 / 239 \\
(9.2 \%)\end{array}$ & $\begin{array}{l}16 / 162 \\
(9.9 \%)\end{array}$ & $\begin{array}{l}12 / 100 \\
(12.0 \%)\end{array}$ \\
\hline $\mathrm{N}$ & $\begin{array}{c}19 / 87 \\
(21.8 \%)\end{array}$ & $\begin{array}{l}33 / 167 \\
(19.8 \%)\end{array}$ & $5 / 43(11.6 \%)$ & $\begin{array}{l}47 / 211 \\
(22.3 \%)\end{array}$ & $\begin{array}{c}9 / 43 \\
(20.9 \%)\end{array}$ & $\begin{array}{c}20 / 83 \\
(24.1 \%)\end{array}$ & $\begin{array}{l}23 / 128 \\
(18.0 \%)\end{array}$ & $\begin{array}{l}37 / 183 \\
(20.2 \%)\end{array}$ & $\begin{array}{l}35 / 174 \\
(20.1 \%)\end{array}$ & $\begin{array}{l}29 / 132 \\
(22.0 \%)\end{array}$ & $\begin{array}{c}15 / 71 \\
(21.1 \%)\end{array}$ \\
\hline NC & $\begin{array}{c}34 / 196 \\
(17.3 \%)\end{array}$ & $\begin{array}{c}93 / 497 \\
(18.7 \%)\end{array}$ & $\begin{array}{c}11 / 97 \\
(11.3 \%)\end{array}$ & $\begin{array}{l}116 / 596 \\
(19.5 \%)\end{array}$ & $\begin{array}{c}18 / 101 \\
(17.8 \%)\end{array}$ & $\begin{array}{l}41 / 239 \\
(17.2 \%)\end{array}$ & $\begin{array}{l}68 / 353 \\
(19.3 \%)\end{array}$ & $\begin{array}{c}94 / 487 \\
(19.3 \%)\end{array}$ & $\begin{array}{c}94 / 476 \\
(19.7 \%)\end{array}$ & $\begin{array}{l}70 / 338 \\
(20.7 \%)\end{array}$ & $\begin{array}{l}33 / 206 \\
(16.0 \%)\end{array}$ \\
\hline \multicolumn{12}{|c|}{ Discontinuations due to treatment-emergent AEs } \\
\hline Placebo & $0 / 27$ & 1/61 (1.6\%) & $0 / 14$ & $1 / 74(1.4 \%)$ & $0 / 14$ & $0 / 28$ & $\begin{array}{c}1 / 46 \\
(2.2 \%)\end{array}$ & $0 / 70$ & $0 / 69$ & $0 / 47$ & $\begin{array}{c}1 / 18 \\
(5.6 \%)\end{array}$ \\
\hline $\mathrm{C}$ & $0 / 116$ & $3 / 230(1.3 \%)$ & $0 / 51$ & $\begin{array}{l}3 / 295 \\
(1.0 \%)\end{array}$ & $\begin{array}{c}1 / 52 \\
(1.9 \%)\end{array}$ & $0 / 104$ & $\begin{array}{l}2 / 188 \\
(1.1 \%)\end{array}$ & $\begin{array}{l}3 / 246 \\
(1.2 \%)\end{array}$ & $\begin{array}{l}3 / 239 \\
(1.3 \%)\end{array}$ & $\begin{array}{l}3 / 162 \\
(1.9 \%)\end{array}$ & $0 / 100$ \\
\hline $\mathrm{N}$ & $\begin{array}{c}5 / 87 \\
(5.7 \%)\end{array}$ & $\begin{array}{l}5 / 167 \\
(3.0 \%)\end{array}$ & $\begin{array}{c}1 / 43 \\
(2.3 \%)\end{array}$ & $\begin{array}{c}9 / 211 \\
(4.3 \%)\end{array}$ & $0 / 43$ & $\begin{array}{c}4 / 83 \\
(4.8 \%)\end{array}$ & $\begin{array}{l}6 / 128 \\
(4.7 \%)\end{array}$ & $\begin{array}{l}5 / 183 \\
(2.7 \%)\end{array}$ & $\begin{array}{l}5 / 174 \\
(2.9 \%)\end{array}$ & $\begin{array}{l}4 / 132 \\
(3.0 \%)\end{array}$ & $\begin{array}{l}5 / 71 \\
(7.0 \%)\end{array}$ \\
\hline NC & $7 / 196(3.6 \%)$ & $13 / 497(2.6 \%)$ & $3 / 97$ (3.1\%) & $\begin{array}{l}17 / 596 \\
(2.9 \%)\end{array}$ & $\begin{array}{l}4 / 101 \\
(4.0 \%)\end{array}$ & $\begin{array}{l}7 / 239 \\
(2.9 \%)\end{array}$ & $\begin{array}{l}9 / 353 \\
(2.5 \%)\end{array}$ & $\begin{array}{l}10 / 487 \\
(2.1 \%)\end{array}$ & $\begin{array}{l}10 / 476 \\
(2.1 \%)\end{array}$ & $\begin{array}{l}9 / 338 \\
(2.7 \%)\end{array}$ & $\begin{array}{l}10 / 206 \\
(4.9 \%)\end{array}$ \\
\hline \multicolumn{12}{|c|}{ Any vasodilatory treatment-emergent $A E$} \\
\hline Placebo & $\begin{array}{c}1 / 27 \\
(3.7 \%)\end{array}$ & $\begin{array}{c}9 / 61 \\
(14.8 \%)\end{array}$ & $\begin{array}{c}2 / 14 \\
(14.3 \%)\end{array}$ & $\begin{array}{c}8 / 74 \\
(10.8 \%)\end{array}$ & $\begin{array}{c}2 / 14 \\
(14.3 \%)\end{array}$ & $\begin{array}{c}1 / 28 \\
(3.6 \%)\end{array}$ & $\begin{array}{c}7 / 46 \\
(15.2 \%)\end{array}$ & $\begin{array}{c}7 / 70 \\
(10.0 \%)\end{array}$ & $\begin{array}{c}7 / 69 \\
(10.1 \%)\end{array}$ & $\begin{array}{c}3 / 47 \\
(6.4 \%)\end{array}$ & $\begin{array}{c}3 / 18 \\
(16.7 \%)\end{array}$ \\
\hline C & $\begin{array}{l}6 / 116 \\
(5.2 \%)\end{array}$ & $\begin{array}{l}35 / 230 \\
(15.2 \%)\end{array}$ & $\begin{array}{c}6 / 51 \\
(11.8 \%)\end{array}$ & $\begin{array}{l}35 / 295 \\
(11.9 \%)\end{array}$ & $\begin{array}{c}5 / 52 \\
(9.6 \%)\end{array}$ & $\begin{array}{l}14 / 104 \\
(13.5 \%)\end{array}$ & $\begin{array}{l}22 / 188 \\
(11.7 \%)\end{array}$ & $\begin{array}{l}32 / 246 \\
(13.0 \%)\end{array}$ & $\begin{array}{l}30 / 239 \\
(12.6 \%)\end{array}$ & $\begin{array}{l}22 / 162 \\
(13.6 \%)\end{array}$ & $\begin{array}{l}9 / 100 \\
(9.0 \%)\end{array}$ \\
\hline $\mathrm{N}$ & $\begin{array}{c}20 / 87 \\
(23.0 \%)\end{array}$ & $\begin{array}{l}40 / 167 \\
(24.0 \%)\end{array}$ & $\begin{array}{c}8 / 43 \\
(18.6 \%)\end{array}$ & $\begin{array}{l}52 / 211 \\
(24.6 \%)\end{array}$ & $\begin{array}{c}8 / 43 \\
(18.6 \%)\end{array}$ & $\begin{array}{c}28 / 83 \\
(33.7 \%)\end{array}$ & $\begin{array}{l}24 / 128 \\
(18.8 \%)\end{array}$ & $\begin{array}{l}46 / 183 \\
(25.1 \%)\end{array}$ & $\begin{array}{l}44 / 174 \\
(25.3 \%)\end{array}$ & $\begin{array}{l}35 / 132 \\
(26.5 \%)\end{array}$ & $\begin{array}{c}14 / 71 \\
(19.7 \%)\end{array}$ \\
\hline NC & $\begin{array}{l}24 / 196 \\
(12.2 \%)\end{array}$ & $\begin{array}{l}103 / 497 \\
(20.7 \%)\end{array}$ & $\begin{array}{c}14 / 97 \\
(14.4 \%)\end{array}$ & $\begin{array}{l}113 / 596 \\
(19.0 \%)\end{array}$ & $\begin{array}{c}14 / 101 \\
(13.9 \%)\end{array}$ & $\begin{array}{l}38 / 239 \\
(15.9 \%)\end{array}$ & $\begin{array}{l}75 / 353 \\
(21.2 \%)\end{array}$ & $\begin{array}{c}99 / 487 \\
(20.3 \%)\end{array}$ & $\begin{array}{c}99 / 476 \\
(20.8 \%)\end{array}$ & $\begin{array}{l}72 / 338 \\
(21.3 \%)\end{array}$ & $\begin{array}{l}28 / 206 \\
(13.6 \%)\end{array}$ \\
\hline \multicolumn{12}{|l|}{ Flushing } \\
\hline Placebo & $0 / 27$ & $0 / 61$ & $0 / 14$ & $0 / 74$ & $0 / 14$ & $0 / 28$ & $0 / 46$ & $0 / 70$ & $0 / 69$ & $0 / 47$ & $0 / 18$ \\
\hline C & $0 / 116$ & $0 / 230$ & $0 / 51$ & $0 / 295$ & $0 / 52$ & 0/104 & $0 / 188$ & $0 / 246$ & $0 / 239$ & $0 / 162$ & $0 / 100$ \\
\hline $\mathrm{N}$ & $0 / 87$ & $1 / 167(0.6 \%)$ & $0 / 43$ & $\begin{array}{c}1 / 211 \\
(0.5 \%)\end{array}$ & $0 / 43$ & $1 / 83(1.2 \%)$ & $0 / 128$ & $1 / 183(0.5 \%)$ & $1 / 174(0.6 \%)$ & $1 / 132(0.8 \%)$ & $0 / 71$ \\
\hline NC & 0/196 & $6 / 497$ (1.2\%) & $0 / 97$ & $\begin{array}{l}6 / 596 \\
(1.0 \%)\end{array}$ & $0 / 101$ & $5 / 239(2.1 \%)$ & $1 / 353(0.3 \%)$ & 4/487 (0.8\%) & 4/476 (0.8\%) & $3 / 338(0.9 \%)$ & $\begin{array}{l}2 / 206 \\
(1.0 \%)\end{array}$ \\
\hline \multicolumn{12}{|l|}{ Headache } \\
\hline Placebo & $1 / 27$ (3.7\%) & $5 / 61$ (8.2\%) & $1 / 14$ (7.1\%) & $5 / 74(6.8 \%)$ & $\begin{array}{c}1 / 14 \\
(7.1 \%)\end{array}$ & $1 / 28(3.6 \%)$ & 4/46 (8.7\%) & $3 / 70(4.3 \%)$ & $3 / 69$ (4.3\%) & $1 / 47$ (2.1\%) & $\begin{array}{c}3 / 18 \\
(16.7 \%)\end{array}$ \\
\hline $\mathrm{C}$ & $0 / 116$ & $12 / 230(5.2 \%)$ & 1/51 (2.0\%) & $\begin{array}{l}11 / 295 \\
(3.7 \%)\end{array}$ & $0 / 52$ & $6 / 104$ (5.8\%) & $6 / 188$ (3.2\%) & 9.246 (3.7\%) & 9/239 (3.8\%) & $8 / 162$ (4.9\%) & $\begin{array}{l}3 / 100 \\
(3.0 \%)\end{array}$ \\
\hline $\mathrm{N}$ & $\begin{array}{c}8 / 87 \\
(9.2 \%)\end{array}$ & $\begin{array}{l}20 / 167 \\
(12.0 \%)\end{array}$ & $\begin{array}{c}4 / 43 \\
(9.3 \%)\end{array}$ & $\begin{array}{c}24 / 211 \\
(11.4 \%)\end{array}$ & $\begin{array}{c}2 / 43 \\
(4.7 \%)\end{array}$ & $\begin{array}{c}14 / 83 \\
(16.9 \%)\end{array}$ & $\begin{array}{l}12 / 128 \\
(9.4 \%)\end{array}$ & $\begin{array}{l}20 / 183 \\
(10.9 \%)\end{array}$ & $\begin{array}{l}20 / 174 \\
(11.5 \%)\end{array}$ & $\begin{array}{c}14 / 132 \\
(10.6 \%)\end{array}$ & $\begin{array}{c}8 / 71 \\
(11.3 \%)\end{array}$ \\
\hline NC & $\begin{array}{l}6 / 196 \\
(3.1 \%)\end{array}$ & $\begin{array}{l}32 / 497 \\
(6.4 \%)\end{array}$ & $\begin{array}{c}2 / 97 \\
(2.1 \%)\end{array}$ & $\begin{array}{c}36 / 596 \\
(6.0 \%)\end{array}$ & $\begin{array}{l}5 / 101 \\
(5.0 \%)\end{array}$ & $\begin{array}{c}35 / 454 \\
(7.7 \%)\end{array}$ & $\begin{array}{l}19 / 353 \\
(5.4 \%)\end{array}$ & $\begin{array}{c}27 / 487 \\
(5.5 \%)\end{array}$ & $\begin{array}{c}27 / 476 \\
(5.7 \%)\end{array}$ & $\begin{array}{c}22 / 338 \\
(6.5 \%)\end{array}$ & $\begin{array}{l}11 / 206 \\
(5.3 \%)\end{array}$ \\
\hline \multicolumn{12}{|l|}{ Oedema } \\
\hline Placebo & $0 / 27$ & $\begin{array}{c}4 / 61 \\
(6.6 \%)\end{array}$ & $\begin{array}{c}1 / 14 \\
(7.1 \%)\end{array}$ & $3 / 74$ (4.1\%) & $\begin{array}{c}1 / 14 \\
(7.1 \%)\end{array}$ & $0 / 28$ & $\begin{array}{c}3 / 46 \\
(6.5 \%)\end{array}$ & $\begin{array}{c}4 / 70 \\
(5.7 \%)\end{array}$ & $\begin{array}{c}4 / 69 \\
(5.8 \%)\end{array}$ & $\begin{array}{c}2 / 47 \\
(4.3 \%)\end{array}$ & $0 / 18$ \\
\hline $\mathrm{C}$ & $\begin{array}{l}6 / 116 \\
(5.2 \%)\end{array}$ & $\begin{array}{l}24 / 230 \\
(10.4 \%)\end{array}$ & $\begin{array}{c}5 / 51 \\
(9.8 \%)\end{array}$ & $\begin{array}{c}25 / 295 \\
(8.5 \%)\end{array}$ & $\begin{array}{c}5 / 52 \\
(9.6 \%)\end{array}$ & $\begin{array}{c}9 / 104 \\
(8.7 \%)\end{array}$ & $\begin{array}{l}16 / 188 \\
(8.5 \%)\end{array}$ & $\begin{array}{c}24 / 246 \\
(9.8 \%)\end{array}$ & $\begin{array}{c}22 / 239 \\
(9.2 \%)\end{array}$ & $\begin{array}{l}15 / 162 \\
(9.3 \%)\end{array}$ & $\begin{array}{l}6 / 100 \\
(6.0 \%)\end{array}$ \\
\hline $\mathrm{N}$ & $\begin{array}{c}14 / 87 \\
(16.1 \%)\end{array}$ & $\begin{array}{l}22 / 167 \\
(13.2 \%)\end{array}$ & $5 / 43(11.6 \%)$ & $\begin{array}{c}31 / 211 \\
(14.7 \%)\end{array}$ & $\begin{array}{c}6 / 43 \\
(14.0 \%)\end{array}$ & $\begin{array}{c}17 / 83 \\
(20.5 \%)\end{array}$ & $\begin{array}{c}13 / 128 \\
(10.2 \%)\end{array}$ & $\begin{array}{l}28 / 183 \\
(15.3 \%)\end{array}$ & $\begin{array}{l}26 / 174 \\
(14.9 \%)\end{array}$ & $\begin{array}{l}21 / 132 \\
(15.9 \%)\end{array}$ & $\begin{array}{c}8 / 71 \\
(11.3 \%)\end{array}$ \\
\hline NC & $\begin{array}{l}19 / 196 \\
(9.7 \%)\end{array}$ & $\begin{array}{l}70 / 497 \\
(14.1 \%)\end{array}$ & $\begin{array}{c}12 / 97 \\
(12.4 \%)\end{array}$ & $\begin{array}{l}77 / 596 \\
(12.9 \%)\end{array}$ & $\begin{array}{l}10 / 101 \\
(9.9 \%)\end{array}$ & $\begin{array}{c}22 / 239 \\
(9.2 \%)\end{array}$ & $\begin{array}{l}57 / 353 \\
(16.1 \%)\end{array}$ & $\begin{array}{l}74 / 487 \\
(15.2 \%)\end{array}$ & $\begin{array}{l}74 / 476 \\
(15.5 \%)\end{array}$ & $\begin{array}{l}52 / 338 \\
(15.4 \%)\end{array}$ & $\begin{array}{l}15 / 206 \\
(7.3 \%)\end{array}$ \\
\hline
\end{tabular}

Abbreviations: AE, adverse event; BMI, body mass index; C, candesartan cilexetil; CV, cardiovascular; eGFR, estimated glomerular filtration rate; LDL, low-density lipoprotein; N, nifedipine GITS; T2DM, type 2 diabetes mellitus. 


\section{a}

Renal impairment (baseline eGFR $<90 \mathrm{~mL} / \mathrm{min}$ )

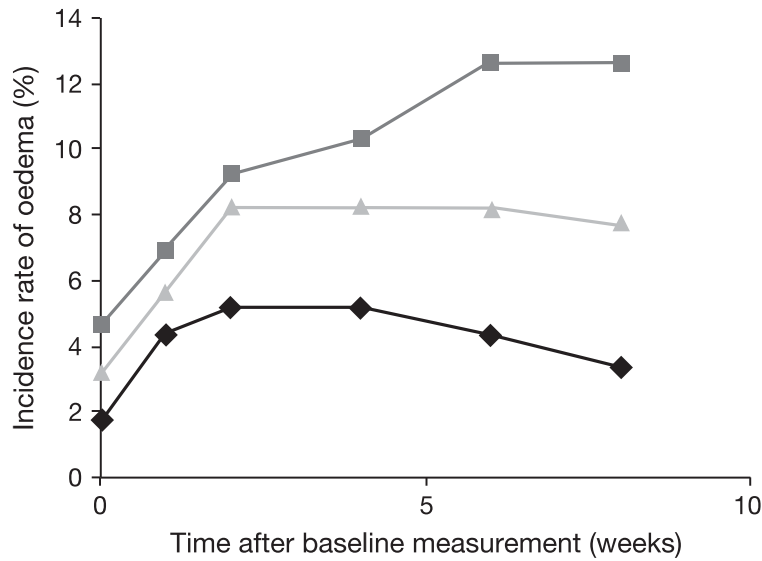

C Hypercholesterolaemia (total cholesterol > $240 \mathrm{mg} / \mathrm{dL}$ )

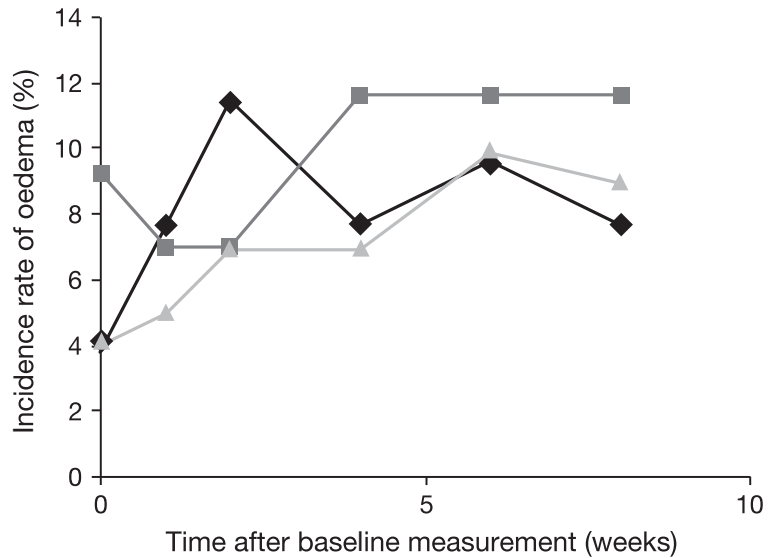

b T2DM

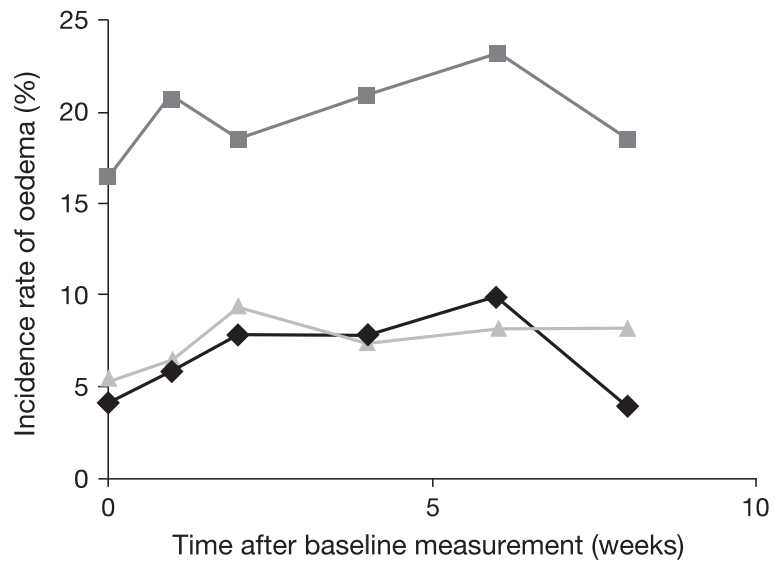

d
Any CV risk factors (T2DM or BMI $\geq 30 \mathrm{~kg} / \mathrm{m}^{2}$

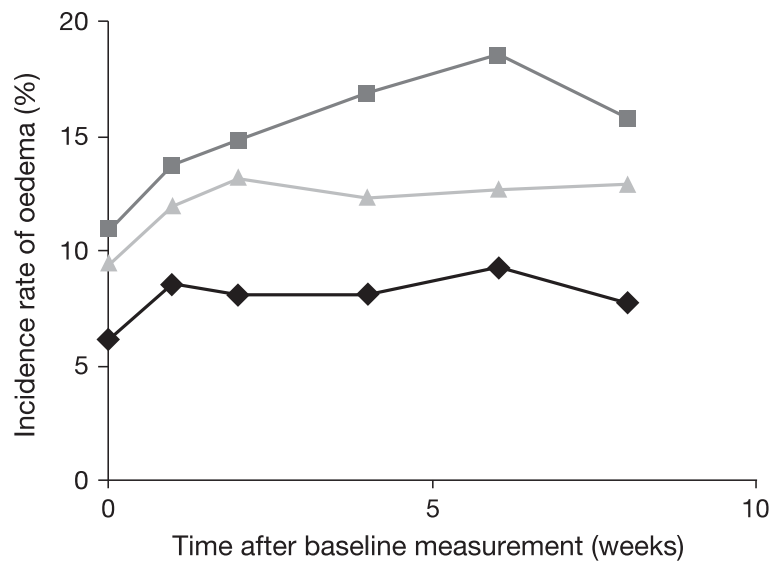

$\mathrm{C}$ mono $-\mathrm{N}$ mono $\rightarrow \mathrm{N} / \mathrm{C} \mathrm{comb}$

Figure 4. Incidence rate of oedema during 8 weeks of treatment with nifedipine GITS $(\mathrm{N} 20,30,60)$ and/or candesartan cilexetil $(C 4,8,16,32)$ in individuals with (a) renal impairment (baseline eGFR $<90 \mathrm{ml} \mathrm{min}^{-1}$ ), (b) T2DM, (c) hypercholesterolaemia (total cholesterol $>240 \mathrm{mg} \mathrm{dl}^{-1}$ ) or (d) any CV risk factors (T2DM or $B M I \geqslant 30 \mathrm{~kg} \mathrm{~m}^{-2}$ or $\mathrm{LDL} \geqslant 130 \mathrm{mg} \mathrm{dl}^{-1}$ ). Abbreviations: BMI, body mass index; C, candesartan cilexetil; CV, cardiovascular; eGFR, estimated glomerular filtration rate; LDL, low-density lipoprotein; N, nifedipine GITS; T2DM, type 2 diabetes mellitus.

clinical trials that renal and CV protection are increased by more intensive BP lowering. ${ }^{7}$ ) For these reasons, the current analyses include control rates using both the updated ESH/ESC recommendations $(<140 / 85 \mathrm{~mm} \mathrm{Hg}$ for patients with diabetes and $<140 / 90 \mathrm{~mm} \mathrm{Hg}$ for other high-risk groups) and the prespecified target $(<130 / 80 \mathrm{~mm} \mathrm{Hg}$ for patients with renal failure and diabetes). The DISTINCT study had an 8-week duration and therefore does not provide information on long-term efficacy and safety. In addition, although analyses of specific high-risk groups (that is, renal impairment and T2DM) were prespecified in the study protocol, the other subgroup analyses (hypercholesterolaemia and presence of CV risk factors) were performed post hoc.

In summary, this sub-analysis of DISTINCT is the first study to examine the effects of nifedipine GITS-candesartan cilexetil in various dose combinations in high-risk populations, including those with renal impairment, T2DM, hypercholesterolaemia or CV risk factors. Consistent with the main outcomes of DISTINCT, these analyses demonstrate that combination therapy is associated with greater reductions in BP and higher control rates in all high-risk subgroups. The combination therapy was well tolerated in these high-risk groups, with a lower incidence of vasodilatory side-effects than nifedipine GITS monotherapy.

What is known about this topic?

- Guidelines recommend initial combination therapy for individuals with hypertension and comorbidities with increased CV risks.

- RAS blockers and $\beta$-blockers have shown beneficial renal and metabolic outcomes.

What this study adds?

- This post hoc analysis of high-risk participants with hypertension in the DISTINCT trial demonstrated the superior efficacy of nifedipine GITS-ARB combination therapy, compared with respective monotherapies and placebo.

- The nifedipine GITS-ARB combination therapy was well tolerated with a better vasodilatory side-effect profile compared with nifedipine GITS monotherapy in high-risk participants, as in all patients in the main DISTINCT trial. 


\section{CONFLICT OF INTEREST}

$\mathrm{G}$ Mancia has received speaker's or consultation fees in the last 2 years from Actavis, Bayer, Böhringer Ingelheim, Covidien, CVRx, Daiichi Sankyo, Ferrer, Lilly, Medtronic Vascular Inc., Menarini Int., Merck Serono, MSD, Novartis, Recordati, Sanofi, Servier, Takeda. AJ Lewin has received research grants in the last 2 years from Abbott Laboratories, AbbVie Inc., ActivX Biosciences Inc., Akros Pharma, Inc., Amarin Pharma, Inc., Amgen Inc., Amylin Pharmaceuticals, AstraZeneca, Bavarian Nordic, Bayer, Boehringer Ingelheim Pharmaceuticals, Bristol-Myers Squibb, Catabasis, Daiichi Sankyo, Elcelyx Therapeutics, Eli Lilly and Company, Esperion Therapeutics, Forest Research Institute, Gilead Sciences, Inc., GlaxoSmithKline, F. Hoffmann-La Roche, Incyte Corporation, Idenix Pharmaceuticals, Isis Pharmaceuticals, Inc., InteKrin Therapeutics, Inc., Kowa Research Institute, Inc., Merck \& Co., Inc., Metabolic Solutions Development Company, N-Gene Pharmaceuticals, Novartis Pharmaceuticals Corp., Novo Nordisk, Omthera Pharmaceuticals Inc., Pfizer Inc., Pharmacopeia, Inc., PhaseBio Pharmaceuticals, Phenomix Corporation, Pronova, Sanofi-Aventis, Sanofi Pasteur, Schering-Plough, Shionogi Inc., Surface Logix, Takeda Pharmaceuticals USA, Inc., Theracos, Inc., TransTech Pharma LLC, TWI Biotechnology, Inc., VIVUS, Inc. and XOMA, LLC. P Harvey has received research grants from AstraZeneca, Merck, Pfizer, Boehringer Ingelheim, Bayer, Ipsen, Sanofi Aventis, Novo Nordisk, Novartis, Takeda, Mitsubushi, Solvay, GlaxoSmithKline, Lilly, Lundbeck, Mundi Pharma, Proctor and Gamble Co and Jannsen. SE Kjeldsen has received lecture honoraria from Bayer, Merck Sharp \& Dohme, and Takeda, and honoraria for consulting from Bayer and Takeda. G Cha, B Gil-Extremera, and G Villa declare 'none', Data collection, analysis and manuscript preparation were sponsored by Bayer HealthCare AG. Editorial assistance was provided by Bill Wolvey of PAREXEL International, which was contracted by the study sponsor (Bayer HealthCare AG).

\section{ACKNOWLEDGEMENTS}

We thank the DISTINCT programme investigators and advisory board members: Agaiby J, Aggarwal N, Ainsworth P, Akhras R, Amaluan V, Ballarin A, Bardauskiene L, Berra FC, Blagden M, Bodalia B, Borghi C, Bundy C, Burgess L, Buynak R, Cafferata A, Cahill T, Capiau L, Capuano V, Casanova R, Cecil J, Cha G, Chapman J, Chilvers M, Christensen S, Cho Y-H, Chung W-B, Cipollone F, Coca A, Colombo H, Contreras EM, Crowley D, Cusco-Prieto B, Decarlini F, Doh J-H, Dzongowski P, Dzyak G, Ellery A, Extremera BG, Farias E, Farrington C, Fidelholtz J, Fouche L, Gabito A, Gainza M, Gani M, Gaunt R, Gelersztein E, Giuliano M, Glazunov A, Glorioso N, Goloschekin B, Gumbley M, Gupta A, Guzman L, Ha J-W, Hart R, Harvey P, Haworth D, Henein S, Henry D, Her S-H, Heyvaert F, Hollanders G, Hominal M, Hong B-K, Hong T-J, Hwang K-K, Jacovides A, Jacqmein J, Jeon HK, Jones N, Kanani S, Kang H, Karpenko O, Kenton D, Kimzey $\mathrm{N}$, Kjeldsen SE, Kovalenko $\mathrm{V}$, Kushnir M, Lasko $\mathrm{B}$, Lee $\mathrm{KJ}$, Lee $N$, Lewin A, Litvak M, Luksiene D, Majul C, Mannarino E, Manuale $O$, Marcadis A, Miller D, Mills R, Misik K, Mortelmans J, O'Mahony M, O'Mahony W, Park C, Pedrinelli R, Petrulioniene Z, Pettyjohn F, Piskorz D, Poss G, Pudi K, Pyun WB, Raad G, Raila G, Ramirez Espinosa MF, Ramlachan P, Rhee M, Rudenko L, Ruiz TS, Ryan J, Schacter G, Shin J-H, Short D, Sica D, Sirenko Y, Slapikas R, Somani R, Stanislavchuk M, Stewart R, Svishchenko $Y$, Sychov O, Teitelbaum I, Tseluyko V, Van Rensburg DJ, Vaquer Perez JV, Via LM, Vico M, Villa G, Vizir V, Vogel D, Wellmann H, Yoo BS.

\section{REFERENCES}

1 Tsai WC. Treatment options for hypertension in high-risk patients. Vasc Health Risk Manag 2011; 7: 137-141.

2 Mancia G, Fagard R, Narkiewicz K, Redon J, Zanchetti A, Bohm M et al. 2013 ESH/ESC Guidelines for the management of arterial hypertension: the Task Force for the management of arterial hypertension of the European Society of Hypertension (ESH) and of the European Society of Cardiology (ESC). $J$ Hypertens 2013; 31: 1281-1357.

3 Sarnak MJ, Levey AS, Schoolwerth AC, Coresh J, Culleton B, Hamm LL et al. Kidney disease as a risk factor for development of cardiovascular disease: a statement from the American Heart Association Councils on Kidney in Cardiovascular Disease, High Blood Pressure Research, Clinical Cardiology, and Epidemiology and Prevention. Hypertension 2003; 42: 1050-1065.

4 Grundy SM, Benjamin IJ, Burke GL, Chait A, Eckel RH, Howard BV et al. Diabetes and cardiovascular disease: a statement for healthcare professionals from the American Heart Association. Circulation 1999; 100: 1134-1146.

5 Emdin CA, Rahimi K, Neal B, Callender T, Perkovic V, Patel A. Blood pressure lowering in type 2 diabetes: a systematic review and meta-analysis. JAMA 2015; 313: 603-615.

6 O'Connor PJ, Vazquez-Benitez G, Schmittdiel JA, Parker ED, Trower NK, Desai JR et al. Benefits of early hypertension control on cardiovascular outcomes in patients with diabetes. Diabetes Care 2013; 36: 322-327.
7 Weber MA, Schiffrin EL, White WB, Mann S, Lindholm LH, Kenerson JG et al. Clinical practice guidelines for the management of hypertension in the community a statement by the American Society of Hypertension and the International Society of Hypertension. J Hypertens 2014; 32: 3-15.

8 Huang XR, Chen WY, Truong LD, Lan HY. Chymase is upregulated in diabetic nephropathy: implications for an alternative pathway of angiotensin II-mediated diabetic renal and vascular disease. J Am Soc Nephrol 2003; 14: 1738-1747.

9 Sowers JR. Effects of calcium antagonists on insulin sensitivity and other metabolic parameters. Am J Cardiol 1997; 79: 24-28.

10 Neutel JM. Prescribing patterns in hypertension: the emerging role of fixed-dose combinations for attaining BP goals in hypertensive patients. Curr Med Res Opin 2008; 24: 2389-2401.

11 Kjeldsen SE, Sica D, Haller H, Cha G, Gil-Extremera B, Harvey P et al. Nifedipine plus candesartan combination increases blood pressure control regardless of race and improves the side effect profile: DISTINCT randomized trial results. $J$ Hypertens 2014; 32: 2488-2498.

12 Kunz R, Friedrich C, Wolbers M, Mann JF. Meta-analysis: effect of monotherapy and combination therapy with inhibitors of the renin angiotensin system on proteinuria in renal disease. Ann Intern Med 2008; 148: 30-48.

13 Whitworth JA. 2003 World Health Organization (WHO)/International Society of Hypertension (ISH) statement on management of hypertension. J Hypertens 2003; 21: 1983-1992.

14 Littlejohn TW III, Majul CR, Olvera R, Seeber M, Kobe M, Guthrie R et al. Results of treatment with telmisartan-amlodipine in hypertensive patients. $J$ Clin Hypertens (Greenwich) 2009; 11: 207-213.

15 Philipp T, Smith TR, Glazer R, Wernsing M, Yen J, Jin J et al. Two multicenter, 8-week, randomized, double-blind, placebo-controlled, parallel-group studies evaluating the efficacy and tolerability of amlodipine and valsartan in combination and as monotherapy in adult patients with mild to moderate essential hypertension. Clin Ther 2007; 29: 563-580.

16 Weir MR, Hsueh WA, Nesbitt SD, Littlejohn TJ III, Graff A, Shojaee A et al. A titrate-to-goal study of switching patients uncontrolled on antihypertensive monotherapy to fixed-dose combinations of amlodipine and olmesartan medoxomil +/- hydrochlorothiazide. J Clin Hypertens (Greenwich) 2011; 13: 404-412.

17 Levey AS, Bosch JP, Lewis JB, Greene T, Rogers N, Roth D. A more accurate method to estimate glomerular filtration rate from serum creatinine: a new prediction equation. Modification of Diet in Renal Disease Study Group. Ann Intern Med 1999; 130: 461-470.

18 National Kidney Foundation. KDOQI Clinical Practice Guidelines for Chronic Kidney Disease: Evaluation, Classification, and Stratification. National Kidney Foundation. http://www2.kidney.org/professionals/KDOQI/guidelines_ckd/p4_ class_g1.htm. Accessed 2 February 2016.

19 National Institutes of Health. High Blood Cholesterol: What You Need To Know. NIH USA. http://www.nhlbi.nih.gov/health/resources/heart/heart-cholesterol-hbcwhat-html. Accessed 2 February 2016.

20 Grundy SM, Pasternak R, Greenland P, Smith S Jr, Fuster V. AHA/ACC scientific statement: assessment of cardiovascular risk by use of multiple-risk-factor assessment equations: a statement for healthcare professionals from the American Heart Association and the American College of Cardiology. J Am Coll Cardiol 1999; 34: 1348-1359.

21 Mancia G, De BG, Dominiczak A, Cifkova R, Fagard R, Germano G et al. 2007 Guidelines for the Management of Arterial Hypertension: the Task Force for the Management of Arterial Hypertension of the European Society of Hypertension (ESH) and of the European Society of Cardiology (ESC). J Hypertens 2007; 25: 1105-1187.

22 James PA, Oparil S, Carter BL, Cushman WC, Dennison-Himmelfarb C, Handler J et al. 2014 evidence-based guideline for the management of high blood pressure in adults: report from the panel members appointed to the Eighth Joint National Committee (JNC 8). JAMA 2014; 311: 507-520.

23 Arai $T$, Ohashi $H$. Angiotensin receptor blockers and microalbuminuria in hypertensive patients with early (microalbuminuric) stage diabetic nephropathy. Mol Med Rep 2008; 1: 391-393.

24 Tamura Y, Kosuga M, Yamashita M, Tomioka S, Sasaki M, Hikita T et al. Renoprotective effects of angiotensin II receptor blocker, candesartan cilexetil, in patients with stage 4-5 chronic kidney disease. Clin Exp Nephrol 2008; 12: $256-263$.

25 Rossing K, Christensen PK, Hansen BV, Carstensen B, Parving HH. Optimal dose of candesartan for renoprotection in type 2 diabetic patients with nephropathy: a double-blind randomized cross-over study. Diabetes Care 2003; 26: 150-155.

26 Féghali RE, Nisse-Durgeat S, Asmar R. Effect of candesartan cilexetil on diabetic and non-diabetic hypertensive patients: meta-analysis of five randomized doubleblind clinical trials. Vasc Health Risk Manag 2007; 3: 165-171. 
27 Mancia G, Parati G, Bilo G, Choi J, Kilama MO, Ruilope LM. Blood pressure control by the nifedipine GITS-telmisartan combination in patients at high cardiovascular risk: the TALENT study. J Hypertens 2011; 29: 600-609.

28 Derosa G, Cicero AF, Bertone G, Piccinni MN, Fogari E, Ciccarelli L et al. Comparison of the effects of telmisartan and nifedipine gastrointestinal therapeutic system on blood pressure control, glucose metabolism, and the lipid profile in patients with type 2 diabetes mellitus and mild hypertension: a 12-month, randomized, double-blind study. Clin Ther 2004; 26: 1228-1236.

29 Mancia G, Brown M, Castaigne A, de Leeuw P, Palmer CR, Rosenthal T et al. Outcomes with nifedipine GITS or Co-amilozide in hypertensive diabetics and nondiabetics in Intervention as a Goal in Hypertension (INSIGHT). Hypertension 2003; 41: 431-436.

30 Elliott HL, Lloyd SM, Ford I, Meredith PA. Improving blood pressure control in patients with diabetes mellitus and high cardiovascular risk. Int J Hypertens 2011; 2010: 490769.

31 Jamerson K, Weber MA, Bakris GL, Dahlof B, Pitt B, Shi V et al. Benazepril plus amlodipine or hydrochlorothiazide for hypertension in high-risk patients. $N$ Engl J Med 2008; 359: 2417-2428.

32 Bakris GL, Sarafidis PA, Weir MR, Dahlof B, Pitt B, Jamerson K et al. Renal outcomes with different fixed-dose combination therapies in patients with hypertension at high risk for cardiovascular events (ACCOMPLISH): a prespecified secondary analysis of a randomised controlled trial. Lancet 2010; 375: 1173-1181.

33 Weber MA, Bakris GL, Jamerson K, Weir M, Kjeldsen SE, Devereux RB et al. Cardiovascular events during differing hypertension therapies in patients with diabetes. J Am Coll Cardiol 2010; 56: 77-85.

34 Roeters van Lennep JE, Westerveld HT, Erkelens DW, van der Wall EE. Risk factors for coronary heart disease: implications of gender. Cardiovasc Res 2002; 53: 538-549.
35 Reiner Z, Catapano AL, De BG, Graham I, Taskinen MR, Wiklund O et al. ESC/EAS Guidelines for the management of dyslipidaemias: the Task Force for the management of dyslipidaemias of the European Society of Cardiology (ESC) and the European Atherosclerosis Society (EAS). Eur Heart J 2011; 32: 1769-1818.

36 Sever PS, Dahlof B, Poulter NR, Wedel H, Beevers G, Caulfield M et al. Prevention of coronary and stroke events with atorvastatin in hypertensive patients who have average or lower-than-average cholesterol concentrations, in the Anglo-Scandinavian Cardiac Outcomes Trial--Lipid Lowering Arm (ASCOT-LLA): a multicentre randomised controlled trial. Lancet 2003; 361: 1149-1158.

37 de la Sierra A. Mitigation of calcium channel blocker-related oedema in hypertension by antagonists of the renin-angiotensin system. J Hum Hypertens 2009; 23: 503-511.

38 Caldeira D, David C, Sampaio C. Tolerability of angiotensin-receptor blockers in patients with intolerance to angiotensin-converting enzyme inhibitors: a systematic review and meta-analysis. Am J Cardiovasc Drugs 2012; 12: 263-277.

(i) This work is licensed under a Creative Commons AttributionNonCommercial-NoDerivs 4.0 International License. The images or other third party material in this article are included in the article's Creative Commons license, unless indicated otherwise in the credit line; if the material is not included under the Creative Commons license, users will need to obtain permission from the license holder to reproduce the material. To view a copy of this license, visit http:// creativecommons.org/licenses/by-nc-nd/4.0/

(c) The Author(s) 2017

Supplementary Information accompanies this paper on the Journal of Human Hypertension website (http://www.nature.com/jhh) 